\title{
HEGEMONI AMERIKA SERIKAT DI SERI KOMIK CAPTAIN AMERICA STEVE ROGERS.
}

\author{
Rafiqoh Fitriani, Hanny Hafiar, FX. Ari Agung Prastowo \\ Universitas Padjajaran Bandung \\ rafiqohf@gmail
}

\begin{abstract}
This research aimed to describe a critical discourse analysis about hegemony where United States positioned their country as superpower country in Captain America: Steve Rogers comic series. Method used in this research was Critical Discourse Analysis Norman Fairclough with qualitative data and critical paradigm. The results of this research showed that Captain America: Steve Rogers comic series has hegemony messages of United States as superpower country. It was reflected through appearance, personality, words, and the ideology of Captain America while positioning the enemy as the opposites of the aspects above. Captain America: Steve Rogers used social, historical, and political factors to ease their hegemony messages being absorbed by reader. The conclusion of this study is Captain America: Steve Rogers comic series have nation branding hegemony messages of the United States as a superpower country. Furthermore, it is expected that the study about hegemony would get more attention because hegemony subject would evolve socially and ideologically in our society.
\end{abstract}

Keywords: Hegemony, Literation, Comic, Captain America, Critical Discourse Analysis.

\section{PENDAHULUAN}

Captain America: Steve Rogers rilis pada bulan Mei 2016 sebagai seri primer paling baru dari seluruh fancise komik Captain America dan berhasil mengejutkan penggemarnya dari seluruh belahan dunia. Pasalnya volume pertama komik ini diakhiri dengan adegan Captain America mengucapkan kalimat legendaris yang menjadi identitas musuh bebuyutannya, "Hail Hydra!"

Captain America pernah menjadi agen Hydra pada komik Captain America: Civil War volume 5 edisi 24 yang rilis di tahun 2007. Meski baik seri Captain America: Civil War maupun seri Captain America: Steve Rogers sama-sama menunjukkan bahwa Captain America tidak sungguh-sungguh merupakan agen Hydra. Sedangkan di versi Captain America: Steve Rogers menunjukkan Red Skull sang pemimpin Hydra menggunakan Cosmic Cube untuk memanipulasi dan menjadikan Captain America sebagai agen Hydra di luar keinginan dari Captain America sendiri.

Komik Captain America lahir di tengah kancah Perang Dunia Keduan (PD II) dan secara terang-terangan digunakan sebagai media propaganda demi kepentingan perang. Sosok Captain America begitu ikonik setelah muncul dalam cover komik pertama Captain America dengan memukul rahang Adolf Hitler. Captain America melejit begitu cepat di kancah dunia superhero dalam sosok tampan nan kharismatik berbalut kostum ketat berlambang khas bendera Amerika Serikat dan membawa pesan-pesan 
sarat kedamaian dari sudut pandang Amerika Serikat sendiri.

Jerman tampil sebagai musuh utama Captain America sejak komik pertama karakter ini rilis, menjadikan Nazi sebagai karakter antagonis utama dalam seri komik Captain America. Namun Captain America juga kerap muncul membasmi musuh Amerika Serikat yang lain: Cina, Jepang, Vietnam, India, Mesir, hingga tentara Nazi Jerman yang menyamar menjadi alien. Begitu heroiknya penggambaran Captain America dibuat, dan sebaliknya, musuh Captain America selalu digambarkan sebagai sosok menjijikan, mengerikan, dan haus kekuasaan.

Seperti halnya Captain America, Hydra pun berkembang dari masa ke masa, beberapa kali pemimpinnya berganti, tapi yang perlu diperhatikan adalah, sebagian besar anggota Hydra berasal dari penjahat dan kriminal kelas internasional, dan hanya segelintir yang berasal dari Amerika Serikat. Hydra sebagai organisasi kriminal internasional kini dipimpin oleh Madame Viper, Gorgon, dan Baron Helmut Zemo. Dalam profile yang disediakan oleh website Marvel dicantumkan bahwa Madame Viper berkebangsaan Hungaria, Baron Helmut Zemo berkebangsaan Jerman, dan Gorgon berkebangsaan Jepang. Jika menilik kembali sejarah Perang Dunia Kedua, ketiga negara di atas merupakan musuh utama Amerika Serikat dimasaitu.

Penggambaran American ideal begitu melekat dalam diri Captain America, baik melalui ucapan, cara berpikir, dan tindakannya.
Secara lebih jelas melalui tokoh Captain America, penggarap Captain America berusaha membangun seperti apa sosok Amerika Serikat di mata dunia. Memiliki kekuatan super, cerdik, gentleman, pembela kebenaran, dan berjiwa pemimpin yang secara jelas berkaitan dengan karakteristik Captain America dan kemudian 'mencoba' menggiring benak masyarakat pada kesimpulan; bahwa Captain America adalah Amerika Serikat itu sendiri. Seperti yang juga dikemukakan pada Analisis Hegemoni Iblis Tidak Pernah Mati Karya Seno Gumira Ajidarma oleh Nurhadi (2004) dari FBS Universitas Negri Yogyakarta, sebuah karya sastra selain sebagai refleksi masyarakatnya, juga mempunyai kemungkinan bersifat formatif terhadap masyarakat. Hal ini merupakan penjabaran teori struktural atau ideologis milik Gramsci.

Wacana dilihat sebagai representasi kondisi sosial dalam masyarakat. Wacana dilihat dalam hubungannya dengan situasi, institusi, kepentingan, dan struktur sosial yang membentuknya. Analisis Wacana Kritis milik Norman Fairclough menjadi metode yang tepat untuk digunakan dalam penyusunan penelitian ini, karena metode ini menyatakan bahwa teks bukanlah sesuatu yang bebas nilai dan menggambarkan realitas apa adanya, namun teks mengandung pesan ideologi tertentu yang dipengaruhi oleh pembuat teks. Sebagaimana peneliti berusaha menganalisa bagaimana Amerika Serikat menyebarluaskan kisah kesuksesan dan kekuatannya kepada dunia, dan bagaimana Amerika Serikat melalui komik 
Captain America: Steve Rogers berusaha membangun identitasnya sebagai negara adikuasa sekalipun karakter utamanya yang selama ini selalu digambarkan tanpa cela tibatiba ditampilkan sebagai karakter antagonis di edisi pertamanya. Selain itu berdasarkan konteks di atas pula peneliti menemukan kemungkinan bahwa komik Captain America: Steve Rogers menggunakan Hydra sebagai media untuk mendiskreditkan ideologi tertentu seperti paham nasionalisme dan fasisme, yang kemudian diarahkan untuk dapat mengangkat ideologi AS yaitu demokratis-patriotis. Peneliti berusaha mengangkat wacana komik Captain America yang digunakan sebagai hegemoni Amerika Serikat untuk mengangkat nama negara, ideologi, sekaligus mengukuhkan posisi Amerika Serikat sebagai pemimpin dunia. Peneliti sangat tertarik untuk mengangkat topik ini dan mencari tahu apakah Amerika Serikat benar menggunakan komik Captain America: Steve Rogers sebagai media hegemoni untuk membentuk persepsi publik tentang Amerika Serikat sebagai negara adikuasa.

Teori hegemoni milik Antonio Gramci didefinisikan sebagai dominasi oleh satu kelompok terhadap kelompok lainnya, tanpa ancaman kekerasan, sehingga ide-ide yang didiktekan oleh kelompok dominan terhadap kelompok yang didominasi dapat diterima sebagai sesuatu yang wajar (common sense). Gramsci membangun suatu teori yang menekankan bagaimana penerimaan kelompok dominan berlangsung dalam suatu proses yang damai, tanpa tindak kekerasan. Media dapat menjadi sarana dimana satu kelompok mengukuhkan posisinya dan merendahkan kelompok lain. Proses marjinalisasi wacana ini berlangsung secara wajar, khalayak tidak merasa dimanipulasi oleh media. (Haramain, 2001:60)

Kata hegeisthai (Yunani) merupakan akar kata dari hegemoni, yang mempunyai pengertian memimpin, kepemimpinan, kekuasaan yang melebihi kekuasan yang lain. Istilah hegemoni berasal dari bahasa Yunani Kuno, 'eugemonia'. Konsep hegemoni banyak digunakan oleh sosiolog untuk menjelaskan fenomena terjadinya usaha untuk mempertahankan kekuasaan oleh pihak penguasa. Penguasa disini memiliki arti luas, tidak hanya terbatas pada penguasa negara (pemerintah) saja.

Ide hegemoni milik Gramsci berasal dari Machiavelli, Gramsci lambangkan citra kekuasaan sebagai centaur, sosok separuh kuda dan separuh manusia yang berasal dari mitologi Yunani. Centaur menjadi sosok kombinasi yang pas antara persetujuan dan koersi, centaur dijadikan simbol dari perspektif ganda suatu tindakan politik, kekuatan dan konsensus, otoritas dan hegemoni, kekerasan dan kesopanan. Koersi senantiasa laten tetapi hanya dipergunakan dalam kasus marjinal, atau kasus yang menyimpang. (Sugiono, 1999: 20).

Pandangan Gramsci mengenai pentingnya kepemimpinan kultural dan ideologi ini membuatnya mengkarakteristikkan pengertian suprastruktur menjadi 'Dua Level Struktur Utama'. Tingkat pertama disebutnya 
sebagai 'Masyarakat Sipil' dan tingkat kedua sebagai 'Masyarakat Politik'. Masyarakat politik merujuk pada institusi yang memiliki kekuatan untuk menunjukkan 'koersi'. Masyarakat sipil ini memainkan peran yang sangat signifikan dalam membentuk kesadaran massa, kemudian bergantung pada kemampuan masyarakat politik untuk melestarikan kontrol sosial politik mereka dengan mengotrol masyarakat sipil. Ringkasnya, pembagian level ini digunakan untuk merepresentasikan dua ranah yang berbeda, yaitu ranah persetujuan dalam masyarakat sipil dan ranah kekuatan yang dipegang oleh masyarakat politik. Kemudian menurut Gramsci, kedua level ini pada satu sisi berkaitan dengan fungsi 'hegemoni' di mana kelompok dominan menangani keseluruhan masyarakat dan di sisi lain berkaitan dengan 'dominasi langsung'. (Gramsci, 1987:289)

Salah satu strategi kunci dari hegemoni adalah 'konstruksi akal sehat'. Jika pemikiranpemikiran dari kelas penguasa dapat diterima sebagai hal yang masuk akal (tidak ada tendensi kelas), kemudian objek ideologis dari mereka tercapai dan kerja ideologis mereka tertutupi. Hegemoni bukanlah hubungan dominasi dengan menggunakan kekuasaan, melainkan hubungan persetujuan dengan menggunakan kepemimpinan politik dan ideologi. Selanjutnya dikatakan bahwa ide dan opini tidak 'lahir' secara spontan dalam benak setiap individu: keduanya memiliki pusat formasi, iradiasi, persebaran, dan persuasi sekelompok orang atau bahkan individu tunggal, yang mengembangkan dan menghadirkan keduanya dalam bentuk realitas politis mutakhir. (Gramsci, 1971: 192-193). Hegemoni adalah sebuah rantai kemenangan yang didapat melalui mekanisme konsensus (consenso) dan bukan melalui penindasan terhadap kelas sosial lain. Itulah sebabnya hegemoni pada hakekatnya adalah upaya untuk menggiring orang agar menilai dan memandang problematika sosial dalam kerangka yang sudah ditentukan (Gramsci, 1976: 244).

Gramsci memandang kesadaran-tujuan manusia melibatkan antara lain; harapan, pikiran, hasrat, ketakutan, dan aksi dari kehendak. Karena gairah yang kuat diperlukan untuk mempertajam intelektualitas dan membantu penciptaan institusi yang lebih menukik (Sugiono, 1999: 24). Sebuah hubungan hegemoni ditegakkan ketika kelompok berkuasa berhasil mendapatkan persetujuan kelompok subordinat atas subordinasi mereka. Dengan kata lain, kelompok-kelompok subordinat menerima ideide dan kepentingan politik kelompok berkuasa seperti layaknya milik mereka sendiri. Dengan demikian legitimasi kekuasaan kelompok berkuasa tidak ditentang karena ideologi, kultur, nilai-nilai, norma dan politiknya sudah diinternalisasi sebagai kepunyaan sendiri oleh kelompok-kelompok subordinat. Begitu konsensus ini didapat, ideologi, kultur, nilainilai, norma, dan politik itu semakin terlihat 'wajar dan legitimate'. (Sugiono, 1999: 37-38) 


\section{METODE PENELITIAN}

Analisis wacana merupakan pemahaman rangkaian tuturan melalui interpretasi semantik yang berkaitan dengan pemahaman bahasa dalam tindak bahasa (what is said from what is done) dan diarahkan kepada masalah memakai bahasa secara fungsional (functional use of language). Fenomena wacana semata-mata dipandang sebagai unit linguistik yang lebih besar daripada klausa atau kalimat. Berkaitan dengan pandangan deskriptif terhadap wacana, Fairclough mengusulkan pengertian wacana sebagai bentuk praktis sosial. Maksudnya adalah wacana sebagai bagian dari bahasa juga merupakan bagian dari komunitas sosial dan tidak keluar dari itu. (Fairclough, 1995:135) Menurut paham analisis wacana kritis (Critical Discourse Analysis) Fairclough, teks bukanlah sesuatu yang bebas nilai dan menggambarkan realitas sebagaimana adanya. Kecenderungan pribadi dari sang produsen teks dan struktur sosial yang melingkupi sang produsen teks ikut mewarnai isi teks. Bahasa tidak netral melainkan membawa pesan ideologi tertentu yang dipengaruhi oleh sang pembuat teks. AWK (Analisis Wacana Kritis) memahami wacana tidak semata-mata sebagai suatu studi bahasa, tetapi analisis wacana kritis juga menghubungkannya dengan konteks. Konteks yang dimaksud adalah konteks praktik kekuasaan yang bertujuan untuk memarginalkan individu atau kelompok tertentu melalui penggunaan kekuasaan dalam memproduksi teks (wacana).
Fairclough membangun suatu model analisis wacana yang mempunyai kontribusi dalam analisis sosial, sehingga ia mengkombinasikan tradisi analisis tekstual yang selalu melihat bahasa dalam ruang tertutup dengan konteks masyarakat yang lebih luas. Titik perhatian besar dari Fairclough adalah melihat bahasa sebagai praktik sosial. Melihat adanya hubungan antara teks yang mikro dan masyarakat yang makro, Fairclough membagi analisis wacana ke dalam tiga dimensi: teks, discourse practice, dan sociocultural practice. (Eriyanto, 2001: 286) Pendekatan ini dikenal dengan pendekatan perubahan sosial (social change approach). Melalui pendekatan perubahan sosial, wacana dapat dianalisis melalui tiga tahapan, yakni tahap analisis level mikro (teks), tahap level meso yakni produksi teks (discourse practice) dan tahap makro (sociocultural practice). Seperti tampak dalam model analisis wacana kritis Norman Fairclough di bawah, teks dianggap sebagai hal yang memiliki konteks baik berdasarkan proses produksi teks atau "text production" dan "process of interpretation" atau proses interpretasi maupun berdasarkan praktik sosiokultural (Fairclough, 1995: 98).

Bagan 1. Model Analisis Wacana Kritis Faircloug

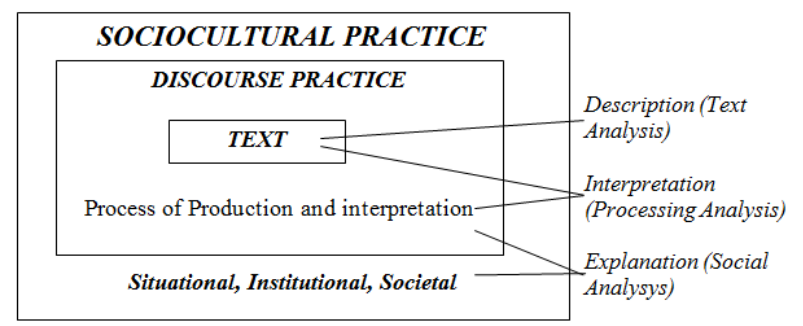


Dengan demikian, untuk memahami wacana (naskah/teks) kita tak dapat melepaskan dari konteksnya. Untuk menemukan "realitas" di balik teks kita memerlukan penelusuran atas konteks produksi teks, interpretasi teks, dan aspek sosial budaya yang mempengaruhi pembuatan teks.

Dua fokus pemikiran utama yang komplementer dalam pemikiran Fairclough, yaitu (Fairclough, 1995:56): (1). Order of Discourse, bersifat umum berbentuk struktur menyeluruh yang berbeda dalam konteks perubahan sosial dan budaya. (2). Communicative Events, bersifat khusus, suatu peristiwa komunikasi yang spesifik seperti editorial surat kabar atau acara televisi.

\section{Praktik Teks}

Fairclough melihat teks dalam berbagai tingkatan. Sebuah teks tidak hanya menampilkan bagaimana sebuah objek digambarkan sekaligus bagaimana hubungan antar objek didefinisikan. Setiap teks pada dasarnya, menurut Fairclough, dapat diuraikan dan dianalisis pada ketiga unsur berikut: (Eriyanto, 2001:289).

Tabel 1. Elemen Dasar Teks

\begin{tabular}{|l|l|}
\hline \multicolumn{1}{|c|}{ UNSUR } & \multicolumn{1}{|c|}{ YANG INGIN DILIHAT } \\
\hline Representasi & $\begin{array}{l}\text { Bagaimana peristiwa, orang, kelompok, situasi, } \\
\text { keadaan atau apa pun ditampilkan dan } \\
\text { digambarkan dalam teks }\end{array}$ \\
\hline Relasi & $\begin{array}{l}\text { Bagaimana hubungan antara wartawan, khalayak, } \\
\text { dan partisipan berita ditampikan dan digambarkan } \\
\text { dalam teks. }\end{array}$ \\
\hline Identitas & $\begin{array}{l}\text { Bagaimana identitas wartawan, khalayak, dan } \\
\text { partisipan berita ditampilkan dan digambarkan } \\
\text { dalam teks. }\end{array}$ \\
\hline
\end{tabular}

\section{Praktik Diskursus}

Discourse practice (Analisis praktik wacana/interpretasi) merupakan dimensi yang berhubungan dengan proses produksi dan konsumsi teks. Eriyanto (2001:287) menulis bahwa sebuah teks berita pada dasarnya dihasilkan lewat proses produksi teks yang berbeda, seperti bagaimana pola kerja, bagan kerja, dan rutinitas dalam menghasilkan berita. Teks diproduksi secara spesifik dengan rutinitas dan pola kerja yang telah terstruktur. Media yang satu mungkin sekali mempunyai pola kerja dan kebiasaan yang berbeda dibandingkan dengan media lain. Analisis praktik diskursus memusatkan perhatian pada bagaimana proses produksi teks. Teks dibentuk lewat sebuah praktik diskursus, yang nantinya menentukan bagaimana teks tersebut diproduksi. Semua praktik tersebut merupakan praktik diskursus yang membentuk wacana. Praktik inilah yang akan menentukan bagaimana teks tersebut terbentuk dalam wacana. Ideologi yang dianut akan tampak dalam proses produksi redaksional dan penentuan berita yang akan menghasilkan berita (Eriyanto, 2001:317). Teks yang memarjinalkan seseorang atau kelompok tertentu bisa jadi lahir dari suatu proses produksi yang melibatkan struktur yang timpang. Struktur organisasi ini meliputi proses pengambilan keputusan, pola rutinitas pembentukan berita, dan melibatkan banyak orang (Eriyanto, 2001:317). 


\section{Praktik Sosiokultural}

"Social practice can be seen as articulations of different types of social element which are associated with particular areas of social life." (Norman Fairclough, 2003: 25) Praktik sosiokultural adalah dimensi yang berhubungan dengan konteks yang berada di luar teks seperti konteks sosial, situasional dan institusional. Analisis ini berdasar pada asumsi bahwa konteks sosial yang berada di luar media dapat mempengaruhi wacana yang muncul di dalam media. Ruang redaksi atau wartawan tak dilihat sebagai sesuatu yang steril atau bebas norma, ideologi, dsb namun sangat ditentukan oleh faktor yang berada di luarnya.

Konteks di sini bisa berarti konteks situasi, atau luasnya adalah konteks dari praktik sebuah institusi media sendiri tetapi juga dalam hubungannya terhadap masyarakat atau budaya politik tertentu. Contohnya budaya media, politik media atau ekonomi media tertentu yang mempengaruhi teks yang dihasilkannya. Analisis dimensi ini dapat menggambarkan bagaimana kekuatan-kekuatan yang ada dalam masyarakat memaknai dan menyebarkan ideologi yang dominan kepada masyarakat (Eriyanto, 2003: 321). Dimensi sociocultural practice tak berhubungan secara langsung dengan teks, namun ia juga menentukan hasil akhir bagaimana teks tersebut diproduksi dan dipahami. Analisis praktik sosiokultural didasarkan pada asumsi bahwa konteks sosial yang ada di luar teks mempengaruhi bagaimana wacana muncul dalam teks. Praktek ini memang tidak berhubungan langsung dengan produksi teks tetapi menentukan teks secara tidak langsung dan dimediasi oleh praktek kewacanaan. Mediasi tersebut meliputi dua hal yaitu; bagaimana teks tersebut diproduksi dan bagaimana teks tersebut diterima dan dikonsumsi.

\section{PEMBAHASAN}

Berdasarkan metode Analisis Wacana Kritis Fairclough, hasil penelitian ini terdiri dari: 1. Hegemoni dalam adegan, 2. Hegemoni dalam dialog, 3. Wacana hegemoni yang berusaha diangkat, dan 4. Faktor sosial-kultural yang mempengaruhi hegemoni Amerika Sebagai Negara adikuasa dalam komik Captain America Steve Rogers.

Gambar 1. Hegemoni AS sebagai negara adikuasa dalam adegan

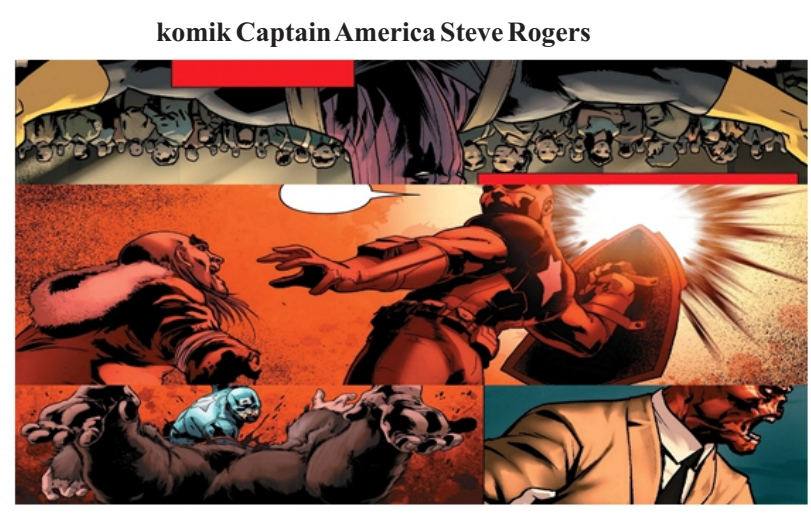

Wacana yang berusaha diangkat oleh hegemoni AS sebagai negara adikuasa dalam dimensi adegan antara lain dengan menunjukkan penjahat selalu merekrut pengikut. Seperti yang ditampilkan pada gambar di atas, Red Skull tengah beretorika untuk mendapatkan simpati dan mengumpulkan anggota baru bagi organisasi terorismenya, organisasi Hydra. Situasi di dalam komik 
Wacana yang berusaha diangkat oleh hegemoni AS sebagai negara adikuasa dalam dimensi adegan antara lain dengan menunjukkan penjahat selalu merekrut pengikut. Seperti yang ditampilkan pada gambar di atas, Red Skull tengah beretorika untuk mendapatkan simpati dan mengumpulkan anggota baru bagi organisasi terorismenya, organisasi Hydra. Situasi di dalam komik Captain America dibangun kental berkaitan dengan permasalahan aktual di dunia nyata, masalah organisasi yang terus bertambah besar dan munculnya sosok-sosok pemimpin terorisme yang siap mengusik kedamaian dunia. Gramsci mengemukakan konsep perang posisi sebagai:

"Perjuangan merebut kekuasaan yang diarahkan pada upaya untuk mengenyahkan ideologi, norma, mitos, politik dan kebudayaan kelompok daripada penyerang kelompok itu secara fisik. Dengan kata lain, perang posisi adalah proses transformasi kultural untuk menghancurkan sebuah hegemoni dan menggantikannya dengan hegemoni lain." (Gramsci, 1971:57)

Berdasarkan konsep diatas, dengan demikian penulis komik Captain America memposisikan ideologi Red Skull dan Hydra sebagai hegemoni yang akan dihancurkan dan digantikan dengan hegemoni lain. Hydra diposisikan sebagai organisasi yang berbahaya dan mengancam kedamaian dunia dengan kemampuan mereka merekrut anggota secara cepat. Alih-alih sepenuhnya melawan dengan kekuatan fisik, ketakutan dan teror pembaca perlu dibangun dengan maksud agar pembaca kemudian mendukung tindakan apapun yang mampu menekan aksi kriminal Hydra dalam merekrut anggota dan menumbuhkan kebencian pada para pemimpin Hydra. Pada dimensi adegan pula, hegemoni dibangun dengan menunjukkan penampilan para superhero dengan kostum bernuansa bendera AS, sebaliknya para penjahat digambarkan dengan penampilan mengerikan. Pada gambar diatas salah satu penjahat yang digambarkan memiliki wajah mengerikan, Red Skull. Gramsci dalam Sugiono mengatakan:

$$
\begin{aligned}
& \text { "Dalam pandangan Gramsci, kesadaran- } \\
& \text { tujuan manusia melibatkan antara lain; } \\
& \text { harapan, pikiran, hasrat, ketakutan, dan } \\
& \text { aksi dari kehendak. Karena gairah yang } \\
& \text { kuat diperlukan untuk mempertajam } \\
& \text { intelektualitas dan membantu } \\
& \text { penciptaan institusi yang lebih } \\
& \text { menukik." (Sugiono: 1999:24) }
\end{aligned}
$$

Kesadaran akan posisi siapa 'pahlawan' dan siapa 'penjahat' dalam benak pembaca secara praktis dibentuk melalui sosok-sosok tersebut yang digambarkan berlawanan. Penjahat digambarkan buruk rupa dan mengerikan, berbanding terbalik dengan pahlawan yang rupawan. Menurut Gramsci pula, gairah yang kuat diperlukan untuk mempertajam intelektualitas dan membantu penciptaan institusi yang lebih menukik. Dengan menggambarkan penjahat sebagai 
sosok buruk rupa dapat menambah poin negatif atas aksi dan mental kriminal mereka, serta menumbuhkan kebencian yang lebih besar lagi dalam benak pembaca terhadap tokoh-tokoh antagonis tersebut atau organisasi yang melatarbelakangi mereka. Pahlawan yang rupawan membangkitkan harapan, sebaliknya penjahat yang buruk rupa membangkitkan ketakutan. Dua hal yang bersimpangan ini sesuai dengan pandangan Gramsci tentang kesadaran dan tujuan manusia dibentuk berdasarkan harapan, pikiran, hasrat, ketakutan, dan aksi dari kehendak, yang kemudian akan menggiring aksi dari kehendak untuk membenci penjahat dan mendukung para pahlawan di dalam komik Captain America: Steve Rogers.

Kecenderungan perbuatan Captain America melakukan tindak kekerasan dengan anggapan bahwa tindakannya itu demi kebaikan yang lebih besar dijelaskan sebagai nilai yang bersifat universal dan kosmopolis, membunuh seseorang merupakan tindakan yang salah. Namun akan berbeda jadinya jika membunuh demi membela diri. Tapi yang tampak pada Captain America juga bukan keduanya. Captain America membunuh dan mencederai seseorang untuk membela kebenaran, bukan untuk membela dirinya. Kekerasan dan perkelahian sudah menjadi bagian dari identitas Captain America sendiri, namun pembaca dan orangorang yang mengenalnya tetap menganggap tindakan Captain America adalah demi membela kebenaran. Hal ini disebabkan oleh lawan-lawan Captain America digambarkan sebagai sosok kriminal atau penjahat. Baik dalam balutan seragam Nazi atau anggota Hydra yang ada di mana-mana.

Gambar 2. Hegemoni AS sebagai negara adikuasa dalam dialog komik Captain America Steve Rogers

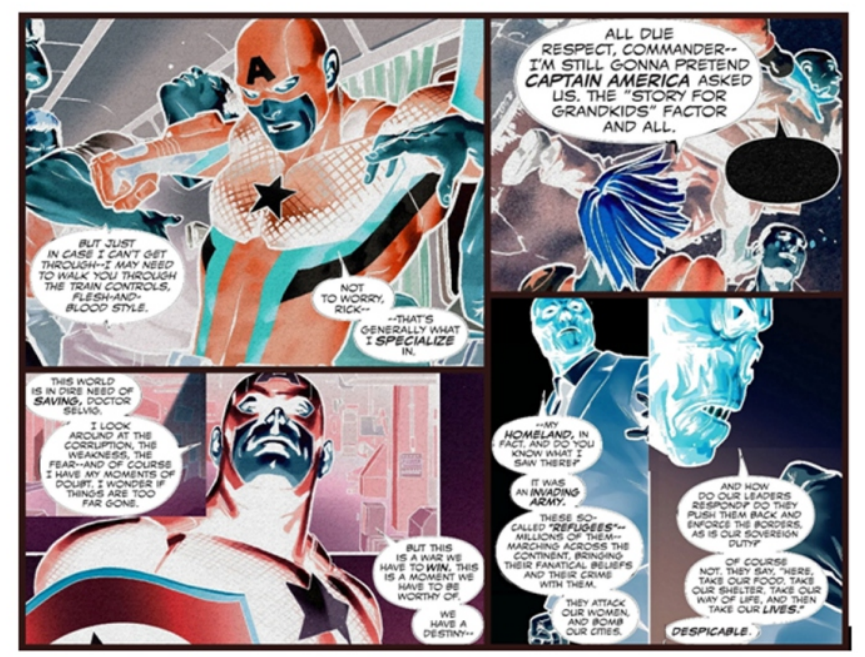

Pada dimensi dialog, hegemoni yang ditampilkan dalam komik Captain America antara lain dengan menunjukkan bahwa seluruh tindakan Captain America merupakan hal yang heroik. Seperti yang diakui oleh karakter ini sendiri di dalam komik ini, 'Blood and Flesh style' adalah keahliannya dalam menegakkan kebenaran. Teori Gramsci memandang jalan demokratik sebagai pilihan menuju kekuasaan. Konsep hegemoni Gramsci menyaratkan perlunya kepemimpinan moral dan kultural pada kelompok yang ingin berkuasa. (Sugiono, 1999: 48) Captain America sosok yang dianggap sebagai kompas moral bagi superhero lainnya, sehingga banyak hal yang dilakukan oleh Captain America menjadi standar bagi pahlawan super lainnya.

Selain itu ditampilkan pula pada dialogdialog di dalam komik, bagaimana ideologi

1Wawancara dengan Bapak Wawan, 13 Oktober 2016 
musuh digambarkan sebagai paham nasionalisme-fasisme dan betapa paham tersebut sangat berbahaya bagi kemanusiaan. Sebagaimana yang ditunjukkan pada gambar diatas, Red Skull tengah beretorika tentang pentingnya rasa nasionalisme dan memiliki masyarakat atas tanahnya sendiri yang kemudian menggiring tindakan-tindakan terorisme dari para anggotanya. Di sisi lain, paham Captain America yang patriotisdemokratis digambarkan merupakan paham terbaik dalam mencapai kedamaian dunia. Hal ini sesuai dengan konsep perang posisi dalam teori hegemoni Antonio Gramsci. Perang posisi adalah proses transformasi kultural untuk menghancurkan sebuah hegemoni dan menggantikannya dengan hegemoni lain. (Gramsci, 1971: 57). Perang posisi ini tampak jelas antara Captain America dan lawanlawannya dalam seri ini, khususnya Red Skull. Captain America juga dikisahkan merencanakan pemberontakan dan pembunuhan Red Skull karena dirinya merasa Red Skull memanfaatkan Hydra demi kepentingan pribadi.

Pada poin yang lain, hegemoni ditampilkan dengan menggambarkan Captain America sebagai standart and leader of justice. Dimana paham, tindakan, dan ucapan Captain America dianggap sebagai aksi seorang pemimpin yang diakui oleh dirinya sendiri dan diamini oleh orang-orang disekitarnya. Seperti yang ditampilkan pada gambar diatas, Captain America percaya bahwa dunia berada dalam bahaya dan dunia membutuhkan bantuannya:
"This world is in dire need of saving, Doctor Selvig.. I wonder if things are too far gone. But this is a war we have to win. This is a moment we have to be worthy of. We have a destiny..." Teori hegemoni yang dimaksud Gramsci menunjuk pada kuatnya pengaruh kepemimpian dalam bentuk moral maupun intelektual, yang membentuk sikap kelas yang dipimpin dalam karakter konsensual. (Haramain, 2001: 85) Captain America digambarkan memiliki pengaruh kepemimpinan yang kuat baik secara moral maupun intelektual

Gambar 3. Wacana Hegemoni yang diangkat dalam komik Captain America: Steve Rogers

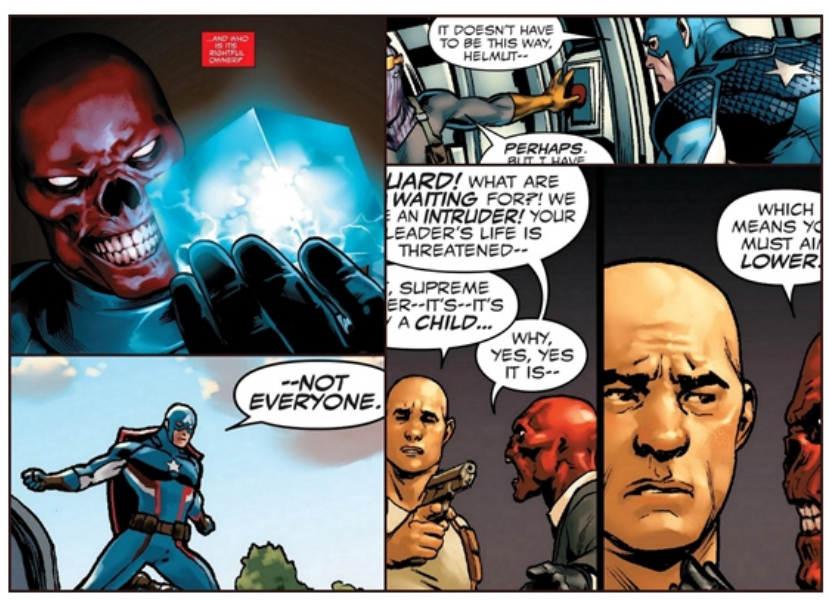

Wacana yang ditampilkan dalam komik Captain America: Steve Rogers antara lain dengan menggambarkan Captain America memiliki kemampuan dan kualitas dalam melakukan konsensus dan koersi. Captain America digambarkan memiliki kekuatan untuk melakukan koersi dan sikap lembut untuk mempersuasi, hal ini serasi dengan konsep hegemoni yang dicetuskan oleh Gramsci yang diilustrasikannya dalam rupa Centaur, sosok separuh kuda dan separuh manusia yang berasal 
dari mitologi Yunani untuk melambangkan kombinasi antara persetujuan dan koersi. (Sugiono, 1999:20). Captain America adalah Centaur, karena Captain America menggunakan both violence and consent untuk mempertahankan keteraturan. Hal ini tampak pada gambar diatas dimana Captain America tetap berusaha mempersuasi Baron Zemo untuk berhenti melakukan kejahatan.

Hegemoni suatu kelas dan anggotanya menjalankan kekuasaan terhadap kelas-kelas di bawahnya dengan cara kekerasan dan persuasi (Simon, 1999:19). Meski dalam kasus Red Skull, persuasi yang dibentuk adalah hasil manipulasi. Dalam teori hegemoni milik Gramsci juga dikatakan agar yang dikuasai tidak hanya merasa mempunyai dan menginternalisasi nilai-nilai serta norma si penguasa, lebih dari itu mereka juga harus memberi persetujuan atas subordinasi mereka terhadap si penguasa (Sugiono, 1999:31).

Gramsci mengemukakan kelompok berkuasa harus mampu membuat kelompok atau massa lain menerima prinsip-prinsip mereka, ide-ide, dan norma atau nilainya sebagai milik mereka juga. Sekali 'pandangan dunia' kelompok yang berkuasa sudah diterima dan diinternalisasi oleh massa atau kelompok lain, maka kelompok berkuasa itu berhasil memantapkan hegemoninya dan dengan sendirinya legitimasinya untuk memerintah terjamin sudah. (Sugiono: 1999, hal 40) 'Pandangan dunia' Amerika Serikat diinternalisasi dan ditanamkan dengan menggambarkan bahwa aksi teror dan kejahatan yang dilakukan Red Skull dan Hydra merupakan concern bagi seluruh manusia, dan bahwa apa-apa yang dilakukan oleh Hydra bertentangan dengan prinsip kemanusiaan yang diemban oleh Captain America.

Amerika Serikat menjalankan fungsinya sebagai Global Cop yang direpresentasikan melalui karakter Captain America. Captain America merupakan intelektual organik atau deputi yang mewakili paham dan pesan hegemoni yang akan disebarkan oleh Amerika Serikat, bahwa -seperti yang telah dijelaskan pada sub-bab sebelumnya- Amerika Serikat merupakan heroes/pahlawan bagi kedamaian dunia, Amerika Serikat tidak terkalahkan, kerusakan yang dibuat Amerika Serikat adalah demi kebaikan, seluruh tindakan Amerika Serikat adalah heroik, ideologi Amerika Serikat adalah ideologi yang terbaik, dan Amerika Serikat adalah leader dan standart of justice. Dengan nilai-nilai ini Amerika Serikat diyakini mampu mengemban posisi sebagai polisi dunia yang bertindak bagi kemashlatan masyarakat secara keseluruhan.

Sebuah hubungan hegemoni ditegakkan ketika kelompok berkuasa berhasil mendapatkan persetujuan kelompok subordinat atas subordinasi mereka. Dengan kata lain, kelompok-kelompok subordinat menerima ideide dan kepentingan politik kelompok berkuasa seperti layaknya milik mereka sendiri. Jika nilai-nilai diatas mengenai penggambaran Captain America dapat dicerna oleh kelompok subordinat atau negara-negara lain sebagai ideide dan kepentingan bersama, legitimasi 
kekuasaan Amerika Serikat tidak akan ditentang karena ideologi, nilai-nilai, norma, dan politiknya sudah diinternalisasi sebagai kepunyaan sendiri oleh kelompok-kelompok subordinat. Begitu konsensus ini didapat, ideologi, kultur, nilai-nilai, norma, dan politik itu semakin terlihat 'wajar dan legitimate' dan ini berarti penggunaan kekuasaan koersif oleh negara menjadi tidak penting lagi. (Sugiono: 1999, 37-38) Ini berarti kekuatan koersif bisa menjadi tidak penting dalam artian tidak lagi digunakan, atau dalam artian tidak lagi dipertanyakan saat digunakan oleh Amerika Serikat.

Hegemoni satu kelompok atas kelompok-kelompok lainnya dalam pengertian Gramscian bukanlah sesuatu yang dipaksakan. Hegemoni harus diraih melalui upaya-upaya politis, kultural, dan intelektual guna menciptakan pandangan dunia bersama bagi seluru masyarakat. Ini berarti kelompok penguasa harus 'menguniversalkan pandangan dan kepentingannya serta harus memastikan bahwa pandangan dan kepentingan itu tidak hanya bisa tetapi juga harus menjadi pandangan dan kepentingan kelompok-kelompok subordinat (Gramsci: 1971, hal 181). Komik Captain America: Steve Rogers memastikan bawah kepentingan dan pandangan Captain America tidak hanya mewakili kelompok tertentu saja, namun juga mewakili kepentingan kelompok-kelompok subordinat dengan mengatasnamakan perdamaian dunia. Terlebih dengan menggambarkan Hydra menyerupai organisasi terorisme yang di kehidupan nyata sudah meninggalkan kengerian di benak orangorang, kemudian diharapkan menciptakan pandangan bahwa eksistensi Captain America adalah pilihan terbaik untuk menangani permasalahan tersebut.

Gambar 4. Faktor sosial-kultural hegemoni AS sebagai negara adikuasa dalam adegan komik Captain America Steve Rogers

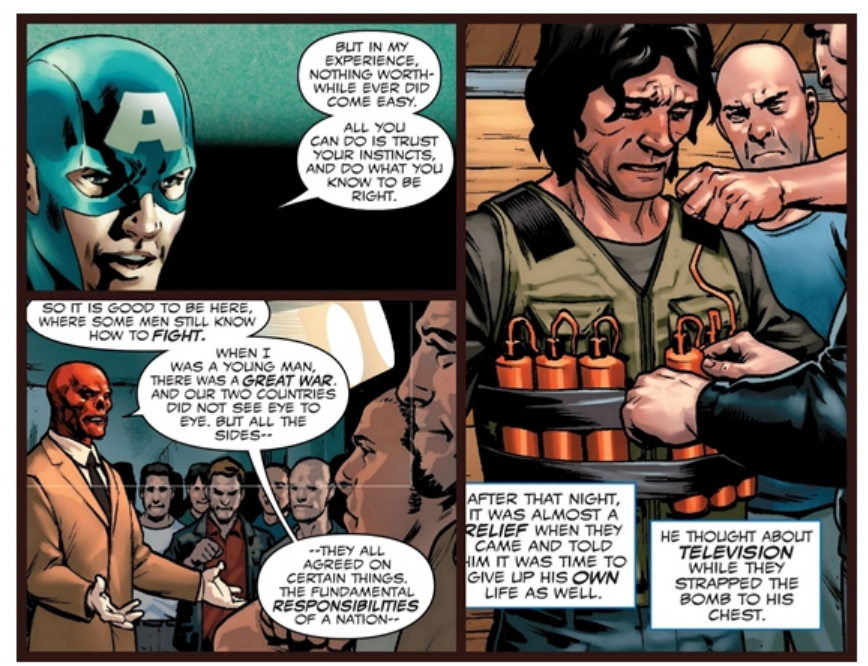

Gambar diatas menunjukkan faktor sosial, sejarah, dan politik yang diangkat dan digunakan untuk menyampaikan hegemoni Amerika Serikat sebagai negara adikuasa di dalam komikini. Gramsci membuat persamaan antara hegemoni dengan kepemimpinan politik maupun pengaruh kultural adalah alasan di balik kepatuhan subordinat terhadap eksploitasi kelas atau kelompok lain. (Sugiono: 1999: 24)

Isu sosial yang ditampilkan adalah terorisme atau kelompok fasisme (Hydra). Identitas Amerika Serikat yang berusaha ditampilkan dalam komik ini berkaitan dengan isu tersebut, dimana Amerika Serikat berusaha ditampilkan sebagai negara yang mendukung toleransi, kemudian menampilkan para penjahat 
sebagai pelaku terorisme yang tengah diperangi oleh Amerika Serikat sendiri. Komik Captain America: Steve Rogers memastikan konflik yang ditampilkan adalah masalah yang bersentuhan, dialami, dan diobservasi secara langsung oleh pembaca. Hal ini dimaksudkan untuk memudahkan pesan hegemoni mereka sebagai negara adikuasa sampai di benak pembaca karena permasalahan yang relevan dengan kehidupan masyarakat sesungguhnya, khususnya terorisme.

Saat Perang Dunia Kedua Captain America diciptakan, sosoknya lahir di tengah kancah peperangan melawan paham-paham yang ditorehkan oleh sejarah sebagai sebuah kejahatan dunia: Nazisme. Karena ini pula sampai tahun 2016, persoalan PDII tetap dibahas di dalam komik Captain America, seperti yang tampak pada gambar diatas tentang bagaimana Red Skull mengenang masa kejayaannya di kala PDII. Gamsci mengatakan, terlepas dari persoalan kekuasaan dalam masyarakat dan ekonomi, sebuah formulasi blok historis yang sukses menandakan adanya kemampuan pemimpin blok untuk membuat ide-ide dan argumen persuasif sekaligus menguniversalkannya. Tanggung jawab untuk membangun sebuah blok historis, memproduksi hegemoni, dan menguniversalisasi pandangan dunia kelompok penguasa dalam rangka mengorganisasikan persetujuan atau partisipasi sukarela masa atau kelompok-kelompok subordinat maupun untuk mengawetkan legitimasi kekuasaan kelompok penguasa yang berada di pundak 'intelektual organisasi' (Gramsci, 1971: 18) Blok historis yang sukses dipandang seperti kemenangan telah Amerika Serikat dan sekutu atas kelompok-kelompok fasis di masa PDII. Blok historis ini kemudian digunakan kembali di dalam plot komik Captain America: Steve Rogers untuk menumbuhkan ide-ide dan argumen persuasif mengenai kepemimpinan dan kehebatan Captain America sebelum diuniversalkan ke seluruh dunia.

Isu politik yang ditampilkan pada komik ini adalah perbedaan paham antara Captain America dan Red Skull. Captain America digambarkan sebagai tokoh protagonis sedangkan Red Skull digambarkan sebagai tokoh antagonis. Keduanya memiliki paham politik yang berbeda, Captain America dengan patriotis-demokratis dan Red Skull dengan nasionalis-fasisme. Hal ini yang kemudian juga menggiring benak pembaca bahwa paham Captain America-lah yang benar dan paham Red Skull adalah paham yang jahat. Komik Captain America mengikis paham nasionalisme yang dikatakan rawan beranjak menjadi fasisme, paham-paham seperti ini yang akan menyulitkan mereka mempengaruhi negaranegara tersebut. Sebaliknya, paham demokrasi memudahkan hegemoni dan pengaruh mereka masuk ke dalam sebuah kelompok atau negara tertentu. Gramsci mengatakan, sebuah hubungan hegemoni ditegakkan ketika kelompok berkuasa berhasil mendapatkan persetujuan kelompok subordinat atas subordinasi mereka. Dengan kata lain, kelompok-kelompok subordinat menerima ide- 
ide dan kepentingan politik kelompok berkuasa seperti layaknya milik mereka sendiri. Dengan demikian legitimasi kekuasaan kelompok berkuasa tidak ditentang karena ideologi, kultur, nilai-nilai, norma dan politiknya sudah diinternalisasi sebagai kepunyaan sendiri oleh kelompok-kelompok subordinat. (Sugiono: 1999, 37-38)

\section{SIMPULAN}

Berdasarkan uraian diatas hegemoni Amerika Serikat sebagai negara adikuasa dalam komik Captain America: Steve Rogers wacana yang ditampilkan adalah dengan menggambarkan Captain America sebagai representasi dari paham Amerika Serikat sendiri, lewat penampilan, paham patriotisdemokratisnya, tindakannya sekalipun merusak tetap heroik, sosoknya adalah seorang pemimpin, dan mengemban fungsi koersikonsensus sekaligus. Di sisi lain Hydra digambarkan seperti gerakan terorisme masa kini, mengemban paham nasionalis-fasisme yang digambarkan sangat berbahaya. Isu sosial, sejarah, dan politik ditampilkan dalam komik ini antara lain: ssu sosial terorisme yang mengincar generasi muda, kasus Snowden, isu sejarah seperti perang dunia II dan perang ideologi, dan di sisi politik ditonjolkan perbedaan-perbedaan ideologi antara Captain America dan musuhnya. Ideologi Captain America digambarkan lebih baik dibanding musuhnya.

\section{REFERENSI}

Eriyanto. (2001). Analisis Wacana, Pengantar Analisis Teks Media. Yogyakarta: LkiS Printing Cemerlang.

Fairclough, Norman. (1989). Language and Power. New York: Addison Wesley Longman.

Fairclough, Norman. (1995). Critical Discourse Analysis. New York: Addison Wesley Longman.

Fairclough, Norman. (2003). Critical Discourse Analysis in Transdisciplinary Research. Dalam Wodak, R. and Chilton, P. 2005. A New Agenda in (Critical) Discourse Analysis. Amsterdam: John Benjamnis Publishing.

Fatimah, Nur (2009) Aspek Wacana dalam Cerita Anak Berbahasa Inggris. Litera: Jurnal Penelitian Bahasa, Sastra dan Pengajarannya. p-ISSN 1412-259 eISSN 2460-813 Vol 8 No. 1 hal. 46-56

Gramsci, Antonio. (1971). Prison Notebooks. London: Lawrence \& Wishart.

Gramsci, Antonio. (1976). Scritti 1915 - 1921, Caprioglio, S. (Ed.). Milan; Mozzi Editore. 
Gramsci, Antonio. (1987). Selections from the Prison Notebooks, Hoare, Q. \& Nowell Smith, G. (Eds). New York: International Publishers.

Haramain, Malik. (2001). PemikiranPemikiran Revolusioner. Malang: Averroes Press

Jazery, M. (2009). "Pertarungan Simbolik dalam Wacana Bantuan Khusus Mahasiswa." Tesis. Tulungagung: Tarbiyah STAIN

Nurhadi. (2004). "Analisis Hegemoni pada Iblis Tidak Pernah Mati Karya Seno Gumira Ajidarma" Tesis. Yogyakarta: Universitas Negri Yogyakarta

Nurhadi. (2004). Analisis Hegemoni pada Iblis Tidak Pernah Mati Karya Seno Gumira Ajidarma. Litera: Jurnal Penelitian Bahasa, Sastra dan Peengajarannya. pISSN 1412-259 e-ISSN 2460-813 Vol 3 No 2 Hal 242-255

Patria, Nezar. (1994). Antonio Gramsci Negara \& Hegemoni. Yogyakarta: Pustaka Pelajar.

Simon, Roger. (1999). Gagasan-gagasan Politik Gramsci. Yogyakarta: Pustaka Pelajar.

Sugiono, Muhadi. (1999). Restructuring Hegemony \& The Changing Discourse of Development. Yogyakarta: Pustaka Pelajar.
Widdowson, H G. (2004). Text, Context, Pretext. Australia: Blackwell Publishing. 